\title{
Trobriand Islanders' Forms of Ritual Communication
}

Gunter Senft

M any discussions of ritual and ritualization, such as Goffman's (1967) essays on face-to-face behavior, emphasize functional criteria and point out that one of the most important functions of rituals is to create and stabilize social relations. Social rites that serve the functions of bonding and aggression-blocking are central to the interaction of living beings. Humans, however, do not have to rely on nonverbal signals to develop rituals; they can also use verbal means to reach this aim.

Thus, with humans we observe not only ritualized patterns and forms of nonverbal behavior that are used as signals in acts of communication but also, and especially, ritualized patterns and forms of verbal communication. In what follows, the term "ritual communication" (RC) subsumes verbal as well as nonverbal patterns and forms of behavior that function as signals that originate and have been generated in processes of ritualization (see Senft 1991: 43).

It is a trivial insight that anyone who wants successfully to research the role of language, culture, and cognition in social interaction must know how the researched society constructs its reality. It is a prerequisite that researchers must be on "common ground" with the researched community. However, as Goffman pointed out, this essential precondition is a rather general one: Every speaker of a natural language must learn the rules of nonverbal and verbal communicative behavior that are valid for her or his speech community. In the course of this learning, one of the most important objectives is to understand and duplicate the construction of the speech community's common social reality. Verbal 
and nonverbal patterns and modes of behavior must be coordinated and harmonized, too.

The duplicated social construction of reality must be safeguarded and secured, especially with respect to possible "sites of fracture" such as cooperation, conflict, and competition within the community. The safeguarding of the duplicated social construction of reality is achieved partly through the ritualization of verbal and nonverbal communication. The ritualization of communication can contribute to relieving tension in critical social situations and to regulating social differences and dissension by increasing the harmonizing functions of speech, by creating and stabilizing social relations, and by distancing emotions, impulses, and intentions. Ritualization of communication can increase the predictability of human behavior; moreover, it can open up space where behavior can be tried out without fear of social sanctions.

Therefore, one can characterize RC broadly as a type of strategic action that, among many other things, helps promote social bonding, block aggression, and dispel elements of danger that might affect a community's social harmony. It acts within the verbal domain by enabling people to voice these elements of danger and bring them up for discussion (see Eibl-Eibesfeldt and Senft 1987: $75 \mathrm{ff}.){ }^{1}$

It goes almost without saying, however, that this does not always work. As Ellen Basso (personal communication) has pointed out, the duplication of the social construction of reality or the social truth of a locution does not always accord with either the speaker's or the listener's experiencing of that situation or one alluded to in the locution. Aggression that might result from this failure is usually suppressed because of the strong general societal requirement to "be nice" even when people do not feel that way. Thus emotions can be calmed, and voicing can be repressed. A society as open as the one in the Trobriand Islands in which I have been studying forms of RC (and any other that offers few closed personal spaces to ensure privacy for its members) depends on its members' having a strong sense of tact. Sometimes one has to pretend not to (over)hear and not to note things, and one must learn at an early age that one does not talk about these things-so the atmosphere is indeed often tense. ${ }^{2}$ The general requirement of tactful behavior, the necessity to be nice, and the positive and successful effects of ritual communication contribute to and create the necessary social harmony in a society such as the one I have been researching. 


\section{Forms of Ritual Communication in the Trobriand Islands}

Since 1982 I have been studying the language and culture of the Trobriand Islanders. Their language, Kilivila, is one of forty Austronesian languages spoken in the Milne Bay Province of Papua New Guinea. It is an agglutinative language, and its unmarked word order pattern is Verb-Object-Subject (VOS). The Austronesian languages spoken in Milne Bay Province are grouped into twelve language families, one of which is labeled Kilivila. The Kilivila family encompasses the languages Budibud (or Nada, with about 200 speakers), Muyuw (or Murua, with about 4,000 speakers), and Kilivila (or Kiriwina, Boyowa, with about 28,000 speakers). Kilivila is spoken on the islands Kiriwina, Vakuta, Kitava, Kaile'una, Kuiawa, Munuwata, and Simsim. The languages Muyuw and Kilivila are each split into mutually understandable local dialects. Typologically, Kilivila is classified as a Western Melanesian Oceanic language belonging to the Papuan-Tip-Cluster group (Senft 1986: 6).

The Trobriand Islanders have become famous, even outside of anthropology, because of the ethnographic masterpieces on their culture published by Bronislaw Malinowski, who did field research there between 1916 and 1920 (Young 2004; see also Senft 1999, 2006). The Trobrianders belong to the ethnic group called Northern Massim. They are gardeners, doing slash-and-burn cultivation of the bush; their most important crop is yams. They are also famous for being excellent canoe builders, carvers, and navigators, especially in connection with the ritualized kula trade, an exchange of shell valuables that covers a wide area of the Melanesian part of the Pacific (see Malinowski 1978 [1922]; Persson 1999). The society is matrilineal but virilocal.

With respect to its communicative forms and sociocultural contexts, ritual communication in the Trobriand Islands, as elsewhere, can be relatively simple and everyday-like-Haviland (this volume) refers to these forms of RC as "little rituals"—or highly complex and situation-specific. These forms can be located on a continuum or cline of structural, (con)textual, and sociocultural complexity. In what follows I illustrate a selection of typical forms of RC that can be observed in the Trobriand Islands. I start with greetings as simple, everyday forms of RC. Then I present and analyze more complex forms of RC that are manifested in insinuating "ditties" and magical formulas. Finally I discuss and illustrate wosi milamala, songs that are sung only during the Trobriand Islanders' harvest festival, after the death of a Trobriander, and during the first mourning ceremonies for the deceased. Wosi milamala 
represent a situation-specific, complex, sophisticated, and extraordinary form of $\mathrm{RC}$ in the Trobriand Islands.

\section{Greetings}

Greetings are probably the best known and described forms of everyday RC (see, e.g., Caton 1986; Duranti 1997). Besides nonverbal greetings such as a friendly smile, a nod, showing the open palm of one's hand, and quickly raising one's eyebrows (Eibl-Eibesfeldt 1989: 118, 453), Trobriand Islanders use the verbal greeting formulas bwena kaukwa'good morning', bwena lalai 'good day', bwena kwaiyai 'good afternoon', and bwena bogi 'good evening' or 'good night'. ${ }^{3}$

These formulas, however, are used primarily at relatively formal occasions such as official welcomings of invited guests. The informal way of greeting consists of the question "Ambeya? [Where are you going to?]" (see also Malinowski 1923: 314). The question is asked first by the greeter and then by the greeted, and both parties answer it truthfully. This greeting ritual continuously assures Trobrianders not only of their integration into a community that cares for its members but also of their protection by the community's social net, which guarantees safety wherever they are. If anything should happen to persons who are greeted like this, whether by accident or because of bad ghosts or black magic, they can be sure that other people know of their whereabouts and will come search for them and help them if necessary. Therefore, this formulaic greeting not only is a ritual of friendly encounter but also creates a social bond and implies safety.

For the sake of completeness, I should add that the official greeting formula used for opening public speeches is "Agatoki guyau, agutoki misinari, agutoki tommota... [Dear chief, dear missionaries, dear people of (name of village)]." Greeting formulas constitute a special register of Kilivila that is metalinguistically labeled biga taloi 'the language of greeting'. Other everyday forms of RC in the Trobriands are, for example, forms of requesting, giving, and taking and what Malinowski defined as "phatic communion," but I do not discuss these forms in detail here (see Senft 1987, 1996a).

\section{Insinuating Ditties}

Among the more complex forms of RC in the Trobriands are insinuating verses, songs, and lullabies that Malinowski (1978 [1922]: 299) called 
"ditties." Many of these ditties accompany games that children (and sometimes also adults) play, and most of them are not just insinuating but explicitly sexual. Every society has things, topics, and themes that are tabooed; one simply does not speak of them. Many such taboos concern sexuality and talk about sexual matters. Sexuality has always been closely connected with taboos in the Trobriand Islands, although it is still true that "sex as such is not tabooed" (Malinowski 1929: 381).

That taboos are ignored and violated-and all the more, the more strictly a society demands observance of them-is well known but often more or less consciously suppressed. A society can secure its members' observance of certain taboos, especially those that are important for its social construction of reality, by allowing the taboos, especially the sociologically less important ones, to become topics of discourse and conversation. A society may even allow its members to imagine the ignorance of taboos-in a fictitious way, of course. This is exactly how and why so-called safety-valve customs develop (see Eibl-Eibesfeldt 1989: 380ff.). The probably prototypical verbal safety-valve custom is the joke. I have described elsewhere how subtle jokes in the Trobriand Islands fulfill this function (Senft 1985a, 1985b), and I illustrate this phenomenon here with insinuating ditties that accompany string figures (see Senft and Senft 1986).

String figures are called ninikula in the Kilivila language, and the ditties accompanying them are vinavina ninikula. Some of them topicalize mythical incidents, animals and plants, the environment in general, events in the lives of the islanders, and individuals and their actions, which are either praised or ridiculed. The vast majority, however, play with sexual allusions or simply are bawdy or obscene jokes. I illustrate two of these vinavina. The first (Senft and Senft 1986: 21 Iff.) thematizes sexual intercourse, which is tabooed while people are working in the gardens (see Malinowski 1929: 68, 455):

Tokwelasi bila va bagula

bibani natala vivila

ebikelasisi
Tokwelasi will go to the garden.

He will find a girl (there).

They will whore.

The second vinavina (Senft and Senft 1986:154ff) thematizes the verbal breaking of the "supreme taboo of the Trobrianders: the prohibition of any tender dealings between brother and sister" (Malinowski 1929: 437). This vinavina clearly constitutes a safety-valve custom: 
Tobabane Tobabane

kwakeye lumta

kwalimati

kusivilaga

kuyomama
Tobabane, Tobabane,

You screw your sister.

You fuck her to death.

You turn around,

You feel weak and tired.

Whenever I discussed this taboo-breaking behavior with Trobrianders, even those who were fully aware of due social decorum justified their tolerance of such verses and the fun people have reciting them by labeling them biga sopa, "joking or lying speech, indirect speech, speech that is not vouched for." Besides the vinavina, the ditties, Trobrianders differentiate and linguistically label a number of other genres, such as sopa 'joke, lie, trick', kasilam 'gossip', and wosi 'songs'. These genres constitute the biga sopa. All of them have specific formal and functional characteristics and are easily recognized by members of the speech community.

This variety is absolutely characteristic of Trobriand forms of talk. It is based on the fact that Kilivila, like any other natural language, is marked by features that include vagueness and ambiguity. Its speakers use these features as stylistic means to avoid possible distress, confrontation, or too much and-for Trobriand Islanders, at least- too aggressive directness in certain speech situations.

If hearers signal that they may be insulted by a certain speech act, speakers can always retreat from what they have said by labeling it sopa, something they did not really mean to say. The simple but pragmatically clearly marked formula asasopa wala $\mathrm{T}$ am just joking', or its shortened version sopa wala '(It's) just (a) joke', then regulates and controls the reactive behavior of the addressees. It signals speakers' "unmarked noncommitment to truth" (Bill Hanks, personal communication). Trobriand etiquette prescribes that hearers must not be offended by utterances explicitly labeled by this formula as sopa - that is, as utterances detached from truth.

Trobriand Islanders have told me - and I have observed this day after day over the last twenty-five years - that they employ this variety of rhetoric in everyday conversation, in small talk, in flirtation, in public debates, in admonitory speeches, and in games, songs, and stories as a means to avoid conflicts and to relax the atmosphere of the speech situation. The biga sopa variety also contributes to putting forward arguments, because it allows speakers to disguise their thoughts verbally and to disagree in a playful way without risking too much personal exposure. Moreover, the biga sopa variety is used for mocking people. 
As a means of irony and parody, it can be used to criticize certain forms of sociologically deviant behavior, asking, relatively mildly, for immediate correction. Finally, the biga sopa variety offers Trobrianders their only license for the verbal breaking of taboos and even for the use of many (but not all) insults and swear words (which are labeled matua). Genres of the biga sopa variety in which taboos are violated are first and foremost classified as sopa-as play, as something fictitious in Trobriand society. ${ }^{4}$ This register thus generates a forum in which the breaking of taboos-and the use of "bad language" (biga gaga), that is, situationallv and stylistically inadequate language-is allowed, if it is done verbally. This forum permits a specially marked way of communication about something "one does not talk about" otherwise.

In sum, the biga sopa variety and its constituting genres, such as the vinavina ninikula, help channel emotions and keep possible aggression under control. The register and its constituting genres secure harmony in Trobriand society and contribute to maintaining islanders' "social construction of reality" (Berger and Luckmann 1966).

\section{Magical Formulas}

Another, more complex form of ritual communication is constituted by magical formulas. The Kilivila label megwa refers to these formulas (and all formulas accompanying rites). The formulas constitute the register of Kilivila called biga megwa 'magic speech'. Until recently, Trobriand Islanders believed strongly in the power of the magical word; they used magic as a means to reach certain aims and to control nature. They distinguish between "black magic," which causes illness or even death, beauty and love magic, magic that is used in building canoes, safety magic against witches and sharks, garden magic, and weather magic. Many of the magical formulas have special labels, such as that for a specific kind of love magic, kasina. There are specialists for certain kinds of magic, and all magic is regarded as personal property.

While reciting-or rather, whispering and murmuring-magical formulas, the magician's accentuation of the words and phrases creates a special, characteristic rhythm. Malinowski (1935: 213) and Weiner (1983: 703) rightly praised the phonetic, rhythmic, alliterative, onomatopoetic, and metaphorical effects, the repetitions, and the prosodically specific characteristics of the language of magic. It is especially these phonetic, suprasegmental, and poetic characteristics that mark the special status of magical formulas as a genre of their own. Moreover, in the majority of these formulas one finds so-called magical words, 
names (of the formula or its former owners), things (such as feathers and spears), and references (to the moon, animals, rivers, and taboos) the meanings of which are unknown even to the magicians themselves (see Senft 1997). Expert magicians perform their rites upon request and are compensated for their services. Their fame depends on their success.

In what follows I present one of Tobwabwana's magical formulas against wild pigs, which may destroy Trobrianders' yam and other gardens. Tobwabwana lives in Tauwema, the village on Kaile'una Island that has been my place of residence since 1982. The formula is used to attract a wild pig to the magician, who waits in the vicinity of the garden with a group of hunters who will help him kill the pig (see Senft 1997: 384): ${ }^{5}$

bulivaleva bulivaleva

bulivaleva bulimalema

bulimalema bulimalema

badududem

5

basobalem kwapusiga

pusigam asamla

asamla asamla

amwala asamla

asamla kudum

10

asamla asamla ampola

asamla asamla togitem

asamla asamla tobulumalem

asamla asamla lopem

asamla asamla katem

15

asamla asamla kopuvem

asamla asamla sile'um

asamla asamla sileveaka

asamla asamla silekekita

asamla asamla kaikem

20

asamla asamla yamam

asamla asamla

bulivaleva

bulivaleva bulivaleva

bulimalema bulimalema
Wild pig, wild pig

Wild pig, wild pig come

Wild pig come, wild pig come

I will charm and kill you

I will call you over and kill you at your flank

Your flank I kill

I kill, I kill

Your head I kill

I kill your tooth

I kill I kill your brow

I kill I kill your loin

I kill I kill your belly (streaky bacon)

I kill I kill your stomach

I kill I kill your innards

I kill I kill your lung

I kill I kill your belly

I kill I kill your large intestine

I kill I kill your small intestine

I kill I kill your hind leg

I kill I kill your foreleg

I kill I kill

Wild pig

Wild pig, wild pig

Wild pig come, wild pig come 
25

bulimalema

badudulem

basibalem

pwapu pusigam

asamla

etna kudokeva

Wild pig come, I will put a spell on you and kill you

I will call you over and kill you

(At your) shoulder, your flank

I kill

It comes, you are bleeding from your mouth

30

kuditilava

ikapitoki

You are bleeding your heart's blood

atakubila

akoluma

yegula Tobwabwana psss

It closes the mouth

I raise the spear to strike

I stick you

I myself Tobwabwana psss

The formula begins with the magician's ordering the wild pig to come to him (lines 1-3) and the announcement that he will put a spell on the animal and kill it (line 4). The noun the formula uses to refer to the wild pig is a magical word; in everyday contexts the noun bwarodina refers to this animal. The verbal expressions badududem/badudulem, basobalem/basibalem, and asamla are magical expressions as well.

The second part of the formula (lines 5-21) lists fourteen body parts of the wild pig and with every part reiterates that the magician will kill it. The list starts with the pig's flank, the place where pigs are usually killed with a spear that is driven through the flank into the heart. This important part of the body is mentioned twice (lines 5-6), and then the formula names the body parts of the pig, beginning with its head and continuing down to its legs. The verbal expression asamla, which refers to the act of the magician's killing the pig, is repeated twentyeight times in this part of the formula.

The third part of the formula (lines 22-25) is a repetition of the first lines of the formula, and the fourth part (lines 26-28) almost identically repeats the first two lines of the second part of the formula (lines 5-6), again mentioning the flank that is so important for killing the animal.

The last part of the formula starts with the statement that the pig comes (line 29), continues with the magician's direct address to the pig, in which he describes what will happen to the animal after he has struck it with the spear in the process of its dying (lines 29-30), and a neutral description of the pig's last action in its death (line 31). It ends with a reference to the magician's actions in killing the pig and an explicit mention of the magician's name. The final onomatopoetic 
sound psss is uttered to distribute the spell into the air so that it will reach the pig, wherever it is.

This formula is typical for the Trobriand megwa. Magicians direct all magical formulas toward specific addressees, among whom are animals, as in this case, things, natural powers, substances, and spirits (see Senft 1997). All these addressees are personalized in the formulas. Some of the addressees are mediating substances (Tambiah 1985: 41) that, like go-betweens, take up the verbal assertions of the formulas, pass them on, and convey them to the final recipient of the magic.

All formulas pursue certain aims, which they will achieve by commanding their addressees to do or change something, by foretelling changes, processes, and developments that are necessary for reaching these aims, or simply by describing the conditions and effects at which the formula aims. Malinowski (1974: 74) characterized this aspect of magic by writing that "it is the use of words which invoke, state, or command the desired aim." About sixty years later, Tambiah (1985: $60,78)$ connected this observation with Austin's speech act theory (Austin 1962) and rightly called these verbal acts "illocutionary" or "performative" acts.

The speech situation in which magicians in the Trobriand Islands find themselves engaged is special indeed. According to my consultants and to all the magicians who presented me with or sold me their formulas, the act of whispering, carrying, or saying the magic is not monological. On the contrary, the magicians emphasize that they engage in a kind of conversation with their addressees. For Trobriand magicians, the addressees of their formulas have to behave like partners in a conversation - at least they have to take the function of listeners-because the power of the magical words forces them to do so. According to my Trobriand consultants, the interactants in the communicative situation of magic are the magician, on one side, and the intermediate or immediate addressee or addressees of the magical formula, on the other. Magicians address their "vis-a-vis" verbally, and the addressees may then be compelled to react nonverbally. That is, they may have to fulfill the commands they hear in the formula and see that its described aims are reached. If they do not react to the magician's formula, it is either because they have to obey another magician's more powerful formula or because the magician has broken a taboo or made a mistake in reciting the formula and therefore cannot successfully force the power of his or her magic onto the addressees. Thus, whether communication between magicians and their addressees is successful or not-from the point of view of the magicians, of course-is completely dependent on the 
nonverbal reaction of the verbally addressed. From the Trobrianders' point of view, the emic perspective, the performance of magic is always a communicative event characterized by a verbal-nonverbal conversation between magician and personalized addressee, regardless of whether the addressee is animate or inanimate. The magician talks to an addressee, which listens and reacts, and therefore both are engaged in a special type of conversation.

This elucidates the dialectics of RC. Rituals and forms of RC can fail, and so it is a risky business to engage in them (see also Howe 2000). If the communication between magicians and their addressees is unsuccessful, magicians can plead the aforementioned explanations for the failure of their magic. If they do this too often, however, they quickly lose their reputation. And not only do they lose face, but the reputations of generations of their relatives who handed down their formulas to their young apprentices are at stake.

For the Trobriand Islander, magic is certainly "a dialectical and dialogical pattern of activity," as Tambiah (1985: 22) pointed out. Tambiah also emphasized that "magical acts are ritual acts" (Tambiah 1985: 60). Werlen's (1984:81) general characterization of ritual as "institutionalized, expressive action" certainly encompasses Trobriand magic, with its emphasis on speech-action. Like many other rituals, Trobriand magic "ritualize[s] man's optimism ... [and] enhance[s] his faith in the victory of hope over fear" (Malinowski 1974:90)—especially with respect to his fear of nature and its forces. Trobriand magic is a specific form of ritual, and the verbal manifestations of this ritual - the magical formulas-are relatively complex forms of ritual communication.

As I mentioned earlier, it is characteristic for Trobriand discourse and communication to use linguistic vagueness and ambiguity as a stylistic means to avoid possible distress, confrontation, or too much and too aggressive directness in everyday speech situations. The magical formulas clearly contradict this observation. With their formulas, Trobriand magicians attempt to force their will on their addressees, and even far-reaching requests are expressed without moderation. Such directness, which strips away the ambiguity and vagueness with which one normally can disguise one's thoughts, is characteristic of the biga pe'ula or biga mokita register-"heavy" or "true, direct" speech. The use of this variety in Trobriand verbal interaction inevitably demands action that for either party involved in the speech event may be dangerous or even fatal.

Yet Trobriand Islanders regard magical formulas as constituting the biga megwa register, a language variety in its own right. Magicians pointed 
out to me that the explicit stylistic marking of the magical formulas as something special and extraordinary was a means to signal addressees that these speech acts were different from the speech acts of general, everyday speech situations - that they will and must put a great strain on the communicative interaction between magicians and their addressees (see also Wheelock 1982: 62). Thus, the formal characteristics of the formulas constitute pronounced signals (Senft 1997: 389). By means of the formal verbal domain, license is sought to strain the communicative interaction. The biga megwa concept uses this license to relieve the tension in this critical situation of social interaction and to ward off any undesirable consequences of its strains. If one characterizes RC as a type of strategic action that, by verbalizing elements of danger more or less explicitly and bringing them up for discussion, contributes to promoting social bonding, blocking aggression, and banning elements of danger that may affect the community's social harmony, then magical formulas are a complex and important form of RC.

\section{Wosi Milamala}

Wosi milamala, the songs of the harvest festival that are also sung after the death of a Trobriander and during the first mourning ceremonies, constitute biga baloma or biga tommwaya, 'speech of the spirits of the dead' or 'old peoples' speech', an archaic variety of Kilivila. Only a few of the elderly living in the Trobriands still know the meaning of these songs, although they are passed on from members of the older generation to a few interested members of the younger one. The genre is in danger of being lost to Trobriand culture. ${ }^{6}$

For Trobrianders, the most important event in the course of the year is still the period of harvest festivals that were first described by Malinowski (1935; see also Senft 1996b: 385ff.). This period is called milamala, and it used to last for almost three months. Since the mid1990s, the Milne Bay government and the Council of Chiefs in the Trobriands have been trying to cut the milamala down to just one day and one night. During my last visits to the Trobriands in 2006 and 2008, I got the impression that these bodies had finally realized their plan. This development illustrates that, especially in the present time of globalization, the ritualization of culture can be manipulated. It seems that this manipulation preferentially affects highly complex and extraordinary forms of RC that, as in the case of the harvest festival, preserve in a specific way important aspects of culture, in this case the Trobriand Islanders' indigenous eschatology. 
In the traditional harvest festival, after getting in the yam harvest, Trobrianders open the milamala with a cycle of festive dances accompanied by drums and songs-the wosi milamala. Upon the decision of the village chief, the important garden magicians, and the expert dancing instructor, the villagers formally present yams, taro, sweet potatoes, fish, sugarcane, and betel nuts to the baloma, the spirits of the dead (Malinowski 1974), just before sunrise. This food distribution is called katukaula. Trobrianders believe that at this time the baloma leave their "underworld paradise" on Tuma Island and visit their former villages.

Then most men and some girls dress up carefully in their traditional clothes. All the dancers decorate their faces with asymmetrical ornaments in red, white, and black. They anoint their bodies with coconut oil and an essence made of fragrant herbs, sprinkle their torsos with small yellow leaves, and put white cockatoo feathers in their hair. They wear armlets made of natural fibers on their upper arms; these emphasize the men's muscles and frame the girls' breasts, thus increasing the wearers' physical beauty. Some of the dancers also wear necklaces, tortoise-shell earrings, and boars' tusks. Moreover, some dancers wear belts made of small white cowrie shells around their waists, knees, or ankles. Most of these adornments mark their wearers' wealth and status within the highly stratified Trobriand society, with its clans and subclans (see Weiner 1976: 237ff.).

After some final magical rites in which the dancers' relatives or the village dance master whispers magical spells on their bodies to make them dance more gracefully, the dancers gather at the center of the village, where in the meantime a group of mostly elderly men, some with drums and some with long sticks, has gathered. As soon as this group begins to sing and drum, the dancers start dancing in circles around them. The wosi milamala are intoned and ended in a specific way. They consist of verses of two to nine lines each, are repeated ad libitum, and have a characteristic melody. The singing and dancing may last for more than three hours. The milamala songs are sung in the language of the baloma, which represents the speech of the ancestors, the "old people," as a salute to the spirits of the dead and to honor and celebrate them (see Senft 2003). The songs are verbal manifestations of the Trobrianders' belief in an immortal spirit, the baloma, that lives in a kind of paradise in the underworld of Tuma Island (see Malinowski 1974). The songs poetically and erotically describe the "life" of the spirits of the dead in their Tuma Island paradise. Trobriand Islanders believe these spirits can be reborn; they can also visit their former villages, 
and they do so regularly during the milamala. During these visits the baloma control whether the villagers living there now still know how to garden, how to celebrate a good harvest, and how to behave even while celebrating exuberantly. "Depending on whether or not they are pleased with what they see, the spirits enhance or hinder the next year's production" of yams (Damon 1982: 231).

Together with the katukaula, the food distribution for the spirits of the dead, the wosi milamala and the song-accompanying dances mark the official beginning of the milamala, the period of harvest festivals. Until the mid-1990s, wosi milamala were also sung in the late evenings during the milamala, and sometimes they formed the transition from one day to the next at this time. This period was characterized by conviviality, flirtation, and amorous adventures. During such festive periods, social norms, rules, and regulations were interpreted more liberally and generously than at other times. This might have led to jealousies and rivalries that, in escalation, would have threatened the community. As my consultants told me, the mere fact that wosi milamala were sung prevented such a development. The songs reminded Trobrianders of the presence of the baloma and of social norms that were valid even for the spirits of the dead, "living" in their paradise. Thus the guardians of the norms of the past were present, checking whether that past was still present in their former villages. The baloma must not be offended by unseemly and indecent behavior, which includes jealousy among bachelors. Keeping this in mind, Trobrianders must control their behavior, especially their emotions, because no one would dare offend the spirits of the dead.

Thus, the past is present during the milamala, and the present during this period is deeply anchored in, and must be similar to, the past. The singing of wosi milamala assures the community that there is a virtually transcendental regulator controlling its members' behavior and thus warding off developments that might prove dangerous for the community. These features of wosi milamala are central for the characterization of RC that I propose.

The importance of the wosi milamala as a complex form of $\mathrm{RC}$ in Trobriand society becomes even more evident when one considers that they are also sung, without accompanying drumming, after the death of a Trobriander and during the first mourning ceremonies (see Senft 1985c; Weiner 1976). Trobriand Islanders believe that the baloma of dead persons, before they go to Tuma Island, stay with their relatives until the corpse is buried. This eschatological "fact" is the link between mourning ritual and the harvest festival. On the basis of this belief, the 
wosi milamala that are sung during the mourning ritual, especially those that describe the carefree life of the spirits in their Tuma paradise, can be interpreted as easing the baloma's grief upon parting. The songs should also console the bereaved, reminding them that dying is just a rite of passage (van Gennep 1909), a transition from one form of existence to another. The songs remind islanders that the present and the future are anchored in the past, and for the baloma the future is not at all different from the past. Life in the Tuma underworld is always the same. There is only a "present." After a few days in the underworld, baloma forget their past, and it is only when they grow tired of their carefree lives there and think of being reborn that a future opens up for them.

Referring to this common knowledge coded in the community's religious superstructure, the songs sung in the biga baloma variety of Kilivila contribute to channeling and controlling emotions during the mourning ceremonies and to maintaining bonds between members of a community that has been struck by death. Wosi milamala, then, not only are sung on specific and more or less "extraordinary" occasions but also can be regarded as a complex and extraordinary form of RC that secures the construction of the society's social reality (Berger and Luckmann 1966) through their norm-controlling and bonding functions. This form of RC also preserves in a specific way important aspects of Trobriand indigenous culture in oral tradition.

Before I present an example of such songs, I want to complete my description of the milamala festival by noting how the end of this period is still officially and publicly marked. In the complete milamala period that I observed in Tauwema village, on Kaile'una Island, the festival ended as the villagers, especially the youngsters, chased the spirits of the dead back to their Tuma underworld by throwing stones, sand, and rotten coconuts and yams toward the invisible baloma. The "past," which was present until then in the villagers' consciousness, was thus chased away. This rite clearly signified that ordinary time, with its clear separation between past, present, and future, would take over again.

In my corpus of Kilivila data I have documented 21 wosi milamala song cycles, with 204 stanzas altogether (including cycles with as few as 2 and cycles with as many as 17 stanzas). Until the mid-1960s the Trobriand Islanders also used this genre to communicate news to their deceased. Most of these songs, however, describe the "lives" of the spirits of the dead in their underworld paradise. In the example that follows, I have ordered the stanzas in such a way that the story told in the cycle emerges. ${ }^{7}$ With only one exception, I never heard wosi milamala cycles sung with ordered stanzas-especially not during the actual milamala 
festival. That the informed Trobriander immediately assigns a story to a stanza belonging to a specific wosi milamala cycle further highlights the "insider knowledge" that is intertwined with this genre.

The following wosi milamala cycle illustrates the genre. The cycle is called "Wosi Oruvekoya"; Oruvekoya is the name of a place near the freshwater grotto Tuyabwau, in the bush close to the village Tauwema:

"Wosi Oruvekoya"

Kwatuyavesa waga

rakeda milaveta

Igineda-igibwau

kwatura'ema tevau

Kwatuyavesa waga

rakeda milaveta

Isirara-Namgereva-budibudi

Kaugepwasa waga-

nagega milaveta

Kusiunisa ina

bukagonusa buita

Bisuya

Namirumeru

biruveyem kunugu

Kumnabegu ina

kusiunisa tau

Bukwasana guwosi

Bigoegu

vaponu

Mbutumgwa venu

miliobu—vaogu

bokone'isa tau

kusiunegu siporu

Sikevai mtbegu

mkwebwau urata

\section{"Oruvekoya Song"}

Turn 'round the canoe's sail, its road is to the open sea.

Our wind-it is very strong, it blows us off the land, men.

Turn 'round the canoe's sail, its road is to the open sea.

$A$ girl with two men-Namgerevaisland far away.

The wrecking of the canoewe wonder about it at the open sea.

You sit together, girls, you make wreaths of flowers.

She will string the flowers,

Namirumeru, she will put it in her hair.

You stay with me, girls, you stay with the men. You will like my song. He'll cry for me with joy between waves and sand.

The noise of the village, Miliobu-yam house-my body, they will look for the man, you sit and sing songs.

Their flirting, my friend, the singing of the young men, 
rokumavai va'ogu-

bidam Valuekoya

[Kaila]

Sikevai nubegu-

kwatudelisa napunuponu

kulimatusa biga

Basikemrura

bivanisegu Tadou

Okunevotu bukwiyayema

tevau

Mkwebwau urata,

rokumevai vavogu-

bidam Varuvekoya

[End of Kaila]

Kwatupelemgwa venu

be'ura'emgwa nogu

okega'ila nogu

bimyegu unata

Kapisim gwadi

bakina koya

Yoyuvanogu varam

gunuvenu her liking of my body-

it will get quiet at Valuekoya.

[Kaila (joining part of the song, refrain)]

Their flirting, my friend-

you walk in line, young girls,

you use the (right) language.

I will sit between the two points, she will refute me (Bwe-)Tadou.

In front of the beach you will love the men.

Your singing, young men,

her liking of my body-

it will be quiet at Varuvekoya.

You change the place of your village, it will open my mind, it will change my mind, she whispers to me, young man.

I am sorry, child,

I will see the mountain.

My mind remembers the crying,

my village.

This song cycle describes the grief of a young man's baloma that has just arrived in a village in the Tuma underworld. The man's name is Bwetadou, and he is still between the worlds of the living and the dead. He has died in a shipwreck and bewails the loss of his girlfriend, whom he knows cannot but refute him now and have love affairs with other men. When she changes her village, he will know that she has married another man. Then he will change his mind and turn toward the baloma girls in the underworld. He feels sorry about what has happened and what will happen-and he still remembers how he was bewailed only a few days ago at his village.

\section{Summary}

The forms of Trobriand ritual communication that 1 have described all contribute to safeguarding and securing the islanders' construction of 
social reality. Greetings are socially integrative devices that continuously help strengthen bonds and stabilize social relations among members of the society. Trobriand ditties, especially the insinuating ones, provide a forum for topicalizing themes that one does not otherwise talk about. Thus they contribute to channeling emotions and keeping frustrations and aggression, caused by the society's strict requirements to adhere to certain taboos, under control. The power of magical words bequeathed by the ancestors to following generations helps strengthen the belief that Trobrianders can master their environment no matter how dangerous and hostile it might be at times. And wosi milamala are verbal manifestations of the Trobrianders' belief in immortal spirits. During the harvest festival these spirits are believed to control people's possibly aggressive behavior patterns, which could turn out to be dangerous for the community. After the death of a Trobriander and during the first mourning ceremonies, the eschatological knowledge encoded in these songs contributes to channeling and controlling emotions and to maintaining bonds among members of a grieving community.

With the exception of the relatively simple forms of greeting, all the forms of Trobriand Islanders' ritual communication that I have described are results of what Ellen Basso and I, in our introduction to this volume, called "artful, performed semiosis." They are "formulaic and repetitive and therefore anticipated within particular contexts of social interaction," and they usually (but not always, as I pointed out in connection with magical formulas) have anticipated consequences. Moreover, they are performed and therefore "subject to evaluation by participants according to standards that are defined in part by language ideologies,... contexts of use, and... relations of power among participants" (Basso and Senft, this volume). In a very specific way, they preserve important aspects of Trobriand Islanders' cultural identity.

There is no metalinguistic expression in Kilivila that can be compared to the "etic" concept of RC. All the Kilivila examples of RC presented in this chapter, however, are metalinguistically labeled, not only with respect to the speech genre to which they belong but also with respect to the variety (or register) of Kilivila they co-constitute. Thus, basic considerations constitutive for the etic concept of RC may have emic equivalents in Kilivila.

\section{Concluding Remarks on Two Daring Hypotheses}

Human ethologists such as Irenaus Eibl-Eibesfeldt have argued that rituals and forms of $\mathrm{RC}$ can be referred back to so-called basic interaction 
strategies (Eibl-Eibesfeldt 1984: 642-645, 1989: 425-547). They claim that all humans have a finite set of these conventionalized strategies at their disposal and assume that these strategies are universal. EiblEibesfeldt differentiated between strategies of group maintenance and bonding, of social learning and teaching, of rank striving, and of fighting. He assumed that the ways people in different cultures try to acquire status, get a gift from someone, invite someone, or block aggression follow in principle the same basic patterns. On the basis of his human ethological field research he concluded: "The superficial appearance of human interactive behaviors varies enormously from culture to culture, but with closer examination we can recognize that the various strategies of social interactions share a universal pattern, based upon a universal rule system (Eibl-Eibesfeldt 1989: 522). Thus-according to Eibl-Eibesfeldt-many rituals and forms of RC can be traced back to, or at least be understood as, the differentiation of these elemental interaction strategies. Despite their richness of variation, they are just culture-specific expressions of these strategies.

Recently, Stephen Levinson (2006b: 61), on the basis of his anthropological-linguistic field research, also postulated a "universal systematics of interaction." He pointed out that "as we learn more about conversational organization ... we see that there are relatively few crucial organizing principles" (2006: 61). This observation, explicitly linked with Conversation Analysis, seems to be in agreement with Eibl-Eibesfeldt's claims with respect to probably universal human elementary interaction strategies. These strategies seem to be part of Levinson's "building blocks for cultural diversity in social interaction," provided by what he called the "interaction engine" (2006b: 62). This interaction engine is understood as "a set of principles that can interdigitate with local principles, to generate different local flavors" (Levinson 2006b: 56). Thus, this set of basic organizing principles "provides the parameters for variation with default values that account for the surprising commonalities in the pattern of ... interchange across cultures" (Levinson 2006b: 62). To put it differently, the enormous variety of human interaction to be observed in different cultures can be attributed to and explained by a few such organizing principles or interaction strategies.

These are daring, though certainly interesting, hypotheses, and they open up another promising approach for researching RC. However, I file a strong caveat here-that to verify or falsify such hypotheses requires a vast amount of empirical and comparative research into the phenomenon. 


\section{Notes}

I thank the national and provincial governments in Papua New Guinea, the Institute for PNG Studies, and the National Research Institute for their assistance with and permission for my research projects. I express my great gratitude to the people of the Trobriand Islands, above all the inhabitants of Tauwema and my consultants, for their hospitality, friendship, and patient cooperation over all these years. Without their help, none of my work on the Kilivila language and Trobriand culture would have been possible. Thanks are also owed to the participants in the Wenner-Gren symposium on ritual communication, in which a first draft of this chapter was discussed.

1. This list of some of the many (cross-cultural and possibly also culturespecific) features that are characteristic and constitutive of forms of RC is the result of joint research and many discussions with Ingrid Bell-Krannhals, Irenaus Eibl-Eibesfeldt, Karl Grammer, Volker Heeschen, Reinhard Schropp, Barbara Senft, and Wulf Schiefenhovel. See also Eibl-Eibesfeldt and Senft 1987; Heeschen 1987; Senft 1987.

2. The concept of tact is an important part of the Trobriand Islanders' moral order. Among other things, it highlights the importance of silence in and for ritual communication. Parents and older members of children's "own little communitfiesj" (Malinowski 1929: 53) explicitly instruct small children in what to do and what not to do. For example, one of the many things one should not do is peep through the mats woven of coconut palm leaves that enclose the wooden frames of the houses. One man of Tauwema lost his eye while doing this as a child-another boy sitting inside the house gouged out his eye with a wooden stick as he peeped through the mats. When children try to do this in Tauwema, one often hears the admonition, "Don't do that, or would you like to look like [the man who lost his eye]?" For further information, see Malinowski 1929: esp. chs. 3 and 8.

3. For Kilivila orthography, see Senft 1986: 14-16.

4. I do not insinuate here that this "play" is ritualized. What is ritualized is the culturally expected reaction of participants in verbal interactions. A Trobriand Islander must not feel offended by utterances that are explicitly labeled sopa by use of the formulaic expression asasopa wala 'I'm just joking' or sopa wala '(It's) just (a) joke'. The biga sopa variety thus allows the breaking of almost all taboos in a kind of "inversed world," without fear of facing severe consequences. Only the five most severe curses in the Trobriands can never be labeled sopa.

5. All my remarks about this formula, and my comments about the characteristic communicative features of biga megwa in general, are based on 
long and intensive discussions I have had with owners of magical formulas, especially with Weyei, the renowned weather magician of Tauwema.

6. My description of wosi milamala and its importance for Trobriand Island society is based on intensive discussions with consultants who still know the meaning of these songs. What 1 present here is thus an emic account of the role of wosi milamala that I present in my etic analysis of forms of RC in the Trobriands.

7. This ordering of the stanzas was approved by my consultants. 